\title{
ARKADIUSZ BARUT
}

Uniwersytet Wrocławski

ORCID: 0000-0002-9347-7072

\section{NOWY MATERIALIZM JAKO IDEOLOGIA POSTPONOWOCZESNOŚCI. SPOJRZENIE KRYTYCZNE}

\section{New Materialism as an Ideology of Post-modernity: A Critical Look}

The concept of new materialism is understood as the direction of political thought, whose main assumptions are the idea of matter regarded as an independent causative agent, and consequently the postulate of political and legal 'empowerment' of non-human beings - animals, plants, parts of inanimate nature, as well as relations, ideas and actions. New materialism appears at the same time as the doctrinal culmination of postmodernism and a post-modernism ideology: contemporary political discourse includes more and more slogans referring to new materialistic ideas: the postulate of environmental protection is considered compatible with the acceptance of the meaning of technology. Both ideas are to justify moving away from recognizing the rights of a human individual as the basic method of legitimisation. The author analyses the new-materialist concept of matter as a structure intended to serve political purposes, indicates the ideological function of this category, i.e. the justification of using the slogans of political identity resulting from material factors (race, sex, etc.) and a departure from the paradigm of an individual as a human rights subject. He concludes that new materialism is, at least potentially, not only an ideological programme of further political and cultural changes, but also an ideology of a supranational political structure, departing from the idea of a welfare state, giving up the appearance of political empowerment of citizens and promoting the political and cultural particularisation of the ruled as a condition of its power.

Keywords: new materialism, actor-network theory, Spinozianism, Bruno Latour, Karen Barad, Elisabeth Grosz, Rosi Braidotti. 


\section{WSTEP}

Nowy materializm jest pojęciem wieloznacznym. Uznaje się go w szczególności za stanowisko naukowe, filozoficzne, a także za kierunek myśli politycznej ${ }^{1}$. Dla nowego materializmu w ostatnim znaczeniu konstytutywna jest idea materii jako samoistnego czynnika sprawczego oraz postulat politycznego i prawnego „upodmiotowienia” bytów pozaludzkich - zwierząt, roślin, części przyrody nieożywionej, a także relacji, idei i działan ${ }^{2}$. W prezentowanym tekście nowy materializm interpretuje jako ideologię, mając przy tym świadomość innych możliwości jego odczytania. Słowa tego używam przy tym w sposób niewartościujący, przyjmując, że ideologia jest zespół idei uzasadniajacy istnienie określonych stosunków władzy politycznej lub też działań zmierzajacych do jej uzyskania ${ }^{3}$. Uznaję, że nowy materializm jest koncepcja szczególnie ważną dla zrozumienia współczesności, co ujawnia się na dwóch poziomach. Jawi się ona jako doktrynalne uwieńczenia politycznego postmodernizmu. Jeśli więc współczesna myśl polityczną i świadomość społeczną interpretować przez pryzmat odejścia idei podmiotu o określonej tożsamości, a zatem uznać myśl postmodernistyczna za kluczowa dla zrozumienia współczesnych zjawisk ideowych, nowy materializm jawi się jako ideologia postponowoczesności. Przede wszystkim jednak we współczesnym dyskursie politycznym coraz częściej spotyka się hasła odwołujące się, chociaż $z$ reguły nie bezpośrednio, do idei nowomaterialistycznych: postulat ochrony przyrody uznawany jest za możliwy do pogodzenia $z$ akceptacja znaczenia techniki, jedna zaś i druga idea uzasadniać ma odchodzenie od uznawania praw jednostki ludzkiej za podstawowa metodę legitymizacji. W swym typie idealnym nowy materializm może stanowić kategorię interpretacji innych współczesnych nurtów ideowych i szerzej - fenomenów współczesnej świadomości społecznej, a nowo-

1 Zob. T. Lemke, New Materialisms: Foucault and the 'Government of Things' .,Theory, Culture \& Society" 2015, nr 32(4), s. 3-4, D. Coole, wywiad [bez tytułu] w: Feministyczne nowe materializmy: usytuowane kartografie, red. O. Cielemęcka, M. Rogowska-Stangret, Lublin 2018, s. 251.

2 O najważniejszych założeniach nowego materializmu, poza literaturą wskazaną poniżej, zob. S. Alaimo, S.J. Hekman (eds.), Material Feminisms, Bloomington 2008; R. Grusin (ed.), The Nonhuman Turn. Minneapolis 2015; T. Bennett, P. Joyce (eds.), Material Powers: Cultural Studies, History and the Material Turn, New York 2010.

3 O pojęciu ideologii np. F. Ryszka, Nauka o polityce. Rozważania metodologiczne, Warszawa, 1984, s. 160-190; R. Skarzyński, Historia myśli politycznej w ujęciu politologicznym. Zarys koncepcji, „Studia Polityczne” 1992, nr 1, s. 113; W. Paruch, Miedzy wyobrażeniami a działaniami. Wybrane aspekty przedmiotowe badań politologicznych nad myśla polityczna, „Polityka i Społeczeństwo” 2004, nr 1, s. 26. 
materialistyczna wizja polityki i społeczeństwa jawi się jako ich ideologiczny punkt dojścia, swoista dystopia ${ }^{4}$.

\section{KONTEKST IDEOWY I ŹRÓDŁA IDEOLOGICZNE NOWEGO MATERIALIZMU}

Nowy materializm jest $z$ reguły kojarzony $z$ myśla feministyczna, niewatpliwie jego czołowe postacie to feministki (m.in. Donna Haraway, Elizabeth Grosz, Rosi Braidotti, Karen Barad), jednak nie może być uznany wyłącznie za jeden $z$ kierunków feminizmu, o czym decyduje zakres tematów poruszanych na jego gruncie wykraczajacy poza hasło zwalczania nierówności, których źródłem ma być różnica płciowa. Ujmujac rzecz na wysokim stopniu ogólności, nowy materializm stanowi reakcję na niespójność, jaka na przełomie XX i XXI wieku powstała $\mathrm{w}$ naukach społecznych oraz w lewicowo-liberalnej myśli politycznej pomiędzy koncentrowaniem się na czynnikach językowych i kulturowych a świadomością skokowo rosnącego znaczenia techniki w życiu codziennym. Jest on również wyrazem odejścia od lewicowo-liberalnego optymizmu ideologicznego lat dziewięćdziesiątych XX wieku, coraz mniej przekonującego w obliczu zjawisk diagnozowanych jako kryzys ekonomiczny i powrót kwestii socjalnej. O kształcie nowego materializmu, jak i jego znaczeniu decyduje jednak wiele innych czynników społecznych, ekonomicznych, politycznych i stricte ideowych ${ }^{5}$.

Nowe materialistki wskazuja źródła swoich doktryn w historii myśli filozoficznej (konceptualizujacc ten wpływ jako jej odczytanie nowatorskie: „poprzeczne”, zob. niżej). Odwołuja się w szczególności do hylozofizmu presokratyków, panteizmu Barucha Spinozy, witalizmu Henri Bergsona, Nietzscheańskiej idei postczłowieka i fenonomenologii ciała Maurice'a Merleau-Ponty'ego. Jako prefiguracja nowego materializmu jawi się materializm dialektyczny Fryderyka Engelsa $z$ monistycznym i dynamicznym rozumieniem materii, jak również $z$ uznaniem praktyki za kryterium prawdy ${ }^{6}$. Współczesnymi inspiracjami nowego ma-

\footnotetext{
4 Próba wykazania, jakie konkretnie interesy stoją za ideologia nowego materializmu przekracza ramy tego tekstu, można jednak sformułować ogólne stwierdzenie, że sa nimi interesy aktorów władzy „rozproszonej”, rzekomo odpodmiotowionej, a przy tym coraz mocniej ingerującej w wolność jednostki i dlatego jawnie rezygnującej z ideologii praw człowieka jako swojego uzasadnienia.

5 Również w gronie jego zwolenników spotyka się pogląd, że stanowi on kolejną intelektualną i ideologiczną modę. V. Kirby, Wywiad [bez tytułu], w: Feministyczne nowe materializmy..., s. 258.

6 L. Kołakowski, Główne nurty marksizmu, t. I, Poznań, 2000, s. 457-458, 462-465, 474-475, 480-481. Na gruncie nowego materializmu trwa dyskusja o jego marksistow-
} 
terializmu mają być koncepcje socjologiczne i filozoficzne (zwłaszcza Michela Foucaulta, Louisa Althussera i Alaina Bourdieu) kładace nacisk na polityczną rolę czynników występujących w życiu codziennym: cielesnych nawyków, troski o zdrowie, seksualności i przejawiających się w nich relacji władzy ${ }^{7}$. O kształcie i ideowym sukcesie nowego materializmu decyduje również rosnacca rola biotechnologii, a także wpływ techniki na życie codzienne ludzi jako bytów pojmowanych (dotychczas) jako biologiczne, pojawienie się organizmów zmodyfikowanych genetycznie i protez techniczno-biologicznych. Sprzyjający nowemu materializmowi klimat intelektualny tworzą również Studia nad Nauka i Technologia (Science and Technology Studies).

Istotne znacznie dla rozwoju nowego materializmu ma upowszechniający się w kulturze masowej obraz świata fizyki kwantowej, w którym nastąpiło odejście od rozumienia materii jako złożonej $z$ obiektów o określonych cechach znajdujacych się w określonych miejscach w określonym czasie, na które oddziałuja siły zewnętrzne, tak jak to było w koncepcjach Kartezjusza i Newtona. Kartezjańsko-Newtonowski obraz rzeczywistości uzasadniał ideę poznania i manipulacji materia przez podmioty wobec niej zewnętrzne. Na poziomie fizyki cząstek elementarnych jest on nieadekwatny. Kolejny argumentem za zmiana obrazu materii przynosi teoria chaosu $z$ jej założeniem istnienia systemów rządzonych przyczynowością „nielinearna,, deterministycznych, a jednak tak skomplikowanych, że ich funkcjonowanie jest niemożliwe do przewidzenia (koncepcja „efektu motyla”) ${ }^{8}$. Nowi materialiści przenoszą konstruowane we współczesnej fizyce teorie epistemologiczne na ontologię (zob. niżej).

Szczególnie istotny wpływ na nowy materializm ma koncepcja aktora sieciowego. Zakłada ona istnienie czynników sprawczych (tzw. aktantów) składających się ze zjawisk zaliczanych „tradycyjnie” do rożnych kategorii - natury i kultury, podmiotów poznających i działających, przedmiotów poznania i działania, działań i aktów poznawczych. Jak ujał to Bruno Latour, istota nowoczesności jest, $z$ jednej strony, mnożenie się naturalno-kulturowych „hybryd” (klimatu, zdrowia itd.), czyli „translacja”. $Z$ drugiej strony, nowoczesność dokonywać ma nieuprawnionego i szkodliwego dzielenia hybryd na fenomeny naturalne i kulturowe, czyli puryfikacji (na biologię i technikę,

skich korzeniach. Zob. J. Bednarek, Różnica epistemologiczna i cięcie sprawcze: materializm marksistowski a nowy materializm, w: Feministyczne nowe materializmy..., s. 89-108.

7 D. Coole, S. Frost, Introducing the New Materialism, w: New Materialism. Ontology, Agency and Politics, eds. D. Coole, S. Frost, Durnham-London 2010 s. 32 i n.

8 Ibidem, s. $7-14$. 
zasoby naturalne i politykę itp.). Na skutek tego hybrydy sa „rozpoznawane", jak twierdzi Latour, tylko w jednym porządku - technicznym lub kulturowym, a przez to pozostaja wyjęte $z$ efektywnej kontroli etyczno-politycznej. Rezultatem ma być, paradoksalnie, społeczna „mobilizacja”, immanentyzacja natury, czyli traktowanie jej jako zespołu przedmiotów możliwych do manipulowania, a $z$ drugiej - uznanie czynników kulturowych za niemożliwe do zmiany, „transcendentne" . Koncepcję Latoura uznaje się za wyraz współczesnego „zwrotu ontologicznego" ${ }^{10}$, stwierdzenie to jest adekwatne również do nowego materializmu.

Szczególnie istotny jest wpływ myśli postmodernistycznej, z która nowy materializm dzieli orientacje posthumanistyczna ${ }^{11}$. Interpretacja postmodernizmu w nowym materializmie jest zarówno krytyczna, jak i afirmatywna. Krytyce podlega przed wszystkim zwrot językowy i uznanie społecznej konstrukcji „rzeczywistości” za jedyny przedmiot interpretacji. Poprzez zapoznanie roli czynników materialnych postmodernizm miał milcząco zakładać adekwatność modernistycznych czy wręcz tradycyjnych kategorii (podmiotu, obiektywnej rzeczywistości), które rzekomo w pełni odrzucił. Miały być one implicite zawarte w emfazie na kulturę traktowanej jako jedyna rzeczywistość godna badania, a zatem quasi-obiektywna, taka samoistna kultura jawić się musi jako wytwór ludzkiej podmiotowości. Według nowych materialistek, skutkiem jest pozostawanie w perspektywie dualizmu (nowożytnej idei podmiotu przeciwstawionego przedmiotowi), a w rezultacie, niemożność odrzucenia esencjalizmu podmiotowego (podmiot ma pewną tożsamość, choćby swobodnie wybraną i konstruowana) i prezentacjonizmu przedmiotowego (rzeczywistość pozapodmiotowa, nawet jeśli nie odbija się w świadomości podmiotu, to jednak pozostaje jego interpretacja, nie ma więc samoistnej sprawczości.) Jak to ujmuje Karen Barad, skoro postmodernizm zakłada obiektywność języka, to przyjmuje reprezentacjonizm, zaś reprezentacjonizm tak w liberalnych koncepcjach politycznych, jak i w teoriach nauki implikuje obiektywne istnienie indywidualnych bytów (posiadających jakąś tożsamość) ${ }^{12}$.

9 B. Latour, Nigdy nie byliśmy nowocześni, przeł. M. Gdula, Warszawa 2011, zwłaszcza s. 21-24, 197-200; K. Abriszewski, Teoria Aktora-Sieci Bruno Latoura, „Teksty Drugie” 2007, nr 1-2, s. 119 .

10 A.W. Nowak, Ontologia a aksjologia - co możemy zyskać, a co stracić, w: Kultura nie-ludzka, red. A. Kil, J. Małczyński, D. Wolska, Wrocław 2015, s. 65-79.

11 O postmodernizmie w kontekście posthumanizmu zob. A. Sulikowski, Posthumanizm a prawoznawstwo, Opole 2013, s. 85-118.

12 K. Barad, Posthumanist Performativity: Toward an Understanding of How Matter Comes to Matter, „Journal of Women in Culture and Society” 2003, t. 28, nr 3, s. 801-804. 
Zarazem nowy materializm stara się odnajdywać w postmodernizmie bliskie mu idee i interpretować go w nowy sposób. Autorami, do których sięga szczególnie chętnie, są Gilles Deleuze i Félix Guattari $\mathrm{i}$ ich hasła maszyn pragnienia, assemblage i kłącza, czemu maja odpowiadać nowomaterialistyczne obrazy „splątania” materii, wyrażające się w oddziaływaniach niemożliwych do wyjaśnienia w kategorii („linearnej”) przyczynowości (zob. niżej). W postmodernizmie „materia" miała funkcjonować pod innymi nazwami, jako to co niewypowiedziane, wyrzucone poza dyskurs, a przez to stanowiące warunek jego krytyczno-politycznej interpretacji - ma być nim sformułowana przez Julię Kristeva idea materii budzącej odrazę - „abiektu”, obraz radykalnej „inności” u Jacquesa Derridy ${ }^{13}$, a przede wszystkim sformułowane przez Foucaulta i Judith Butler koncepcje ciała jako konstrukcji dyskursywnej, wyrazu pola władzy. Według Barad autorzy ci mieli jednak nie zauważać, że prawdziwa destabilizacje pola władzy przyniesie dopiero upodmiotowienie samej materii ${ }^{14}$. Nowy materializm zamiast reprezentacjonizmu promuje „performatywizm” i ideę materii jako czynnika sprawczego ${ }^{15}$.

\section{POLITYCZNA KONCEPCJA MATERII}

W nowym materializmie materia nie jest postrzegana jako zbiór przedmiotów o określonych cechach, nurt ten nie jest więc materializmem w sensie mechanistycznym, lecz monizmem. Na jego gruncie materia jest pojęta na sposób spinozjański, stanowić ma ona aktywną, samostwarzającą się i wciąż zmieniającą się rzeczywistość, na którą składa się zarówno materia „tradycyjnie” pojęta, to jest przedmioty poznania i działania, ale także podmioty poznające, wiedza o materii, wszelkiego rodzaju działania, w tym polityczne. Tak pojęta materia stanowi więc całość świata. Istotne jest, że ani ontologicznie, ani etycznie czy politycznie żaden $z$ jej rodzajów nie jest wyróżniony. Wszystkie postacie materii pozostaja w związu, mogą być prowizorycznie oddzie-

${ }^{13}$ H. Meißner, wywiad [bez tytułu], w: Feministyczne nowe materializmy..., s. 264.

14 Jak to ujmuje Barad, Michel Foucault dostrzegał polityczne znaczenie ciał konstruowanych zarówno przez dyskursywne, jak i niedyskursywne (materialne) praktyki, jednak skoncentrowanie się na języku uniemożliwiło dostrzeżenie znaczenia materialnej sprawczości tych drugich. Niewystarczająca dla celów politycznych miała być również koncepcja Butler, która dostrzegła dynamikę materii - okoliczność, że kształty i granice ciała sa konstytuowane przez dyskurs. Jednak przyjęła w ten sposób, implicite, że materia jest elementem biernym, sprawczość na gruncie koncepcji Butler ma być możliwa wyłącznie dzięki nieciagłości dyskursu, konstytutywnemu zewnętrzu, cesze języka, a nie samej materii. K. Barad, Posthumanist..., s. 804-811, 825 .

15 Ibidem, s. 802-803, 825-826. 
lone wyłącznie dla celów analitycznych lub heurystycznych, ewentualnie dla opisu materii w błędnych, „tradycyjnych” kategoriach. Właściwym sposobem jej badania ma być nie jej klasyfikacja, lecz jej „kartografia,” to jest poznawanie jej przejściowych stanów, a właściwy sposób interpretacji tych badań ma wyrażać postulat „poprzeczności”, to jest łaczenia ustalonych kategorii w celu ich przekraczania ${ }^{16}$.

$\mathrm{Na}$ gruncie nowego materializmu podział na ontologię i epistemologię ulega jednak zatarciu. Dla oddania nowomaterialistycznego rozumienia materii najwłaściwsze jest sięgnięcie do koncepcji Karen Barad. Autorka ta, powołując się na współczesna filozofię nauki (Ian Hacking, Joseph Rouse), wskazuje na potrzebę zerwania $z$ kartezjańskim reprezentacjonizmem, opartym na założeniu bezpośredniego i pewnego dostępu do ludzkich obrazów świata, odróżnionych od rzeczywistości obiektywnej, a przez to zerwania $z$ rozróżnieniem podmiotu i przedmiotu ${ }^{17}$. Odwołuje się również do dorobku współczesnej fizyki, zwłaszcza do kopenhaskiej interpretacji mechaniki kwantowej. Teoria ta, sformułowana przez Nielsa Bohra, zakłada, że na „poziomie" czastek elementarnych akt badawczy tworzy badana rzeczywistość. O ile jednak, jak przyznaje sama Barad, Bohr traktował swa koncepcje jako epistemologiczna, ona przypisuje jej znaczenie onto$\operatorname{logiczne}^{18}$. Nie ma sensu, jej zdaniem, wyodrębniać w materii przedmiotów o trwałej tożsamości, o ile w jakimś sensie można więc mówić o istnieniu przedmiotów, to tylko jako o przejściowym stanie materii. Podstawowym składnikiem rzeczywistości nie mają być także zjawiska czy idee zjawisk, lecz relacje, pierwotne wobec tego, co w nich pozostaje. Między tym, co pozostaje w relacji, zachodzi, jak to ujmuje Barad, intraakcja, której idea jest odmienna od idei interakcji między zjawiskami o określonych cechach. Barad posługuje się tu obrazem nawiązującym do kolejnego pojęcia $z$ dziedziny mechaniki kwantowej, a mianowicie splątania (entanglement) kwantowego, używanego na określenie zjawiska, które, o ile próbować je interpretować na poziomie makroskopowym, jawi się jako niewytłumaczalne powiązanie ze sobą dwóch cząstek, ujawniające się przy pomiarze obu tych cząstek jako układu, a „znikające” przy pomiarze każdej cząstki odrębnie. Materia tak pojęta nie jest powiązana, zdaniem Barad, zależnościami przyczynowymi, możliwymi do wyabstrahowania od procesu poznaw-

16 R. Dolphijn, I. van der Tuin, Nowy materializm. Wywiady i kartografie, przeł. J. Czajka, A. Handke, J. Maliński, A. Marcisz, C. Rudnicki, T. Wiśniewski, Gdańsk-Poznań-Warszawa, 2018, s. 77-92.

17 K. Barad, Posthumanist...,s. 803-807.

18 Ibidem, s. 813 i n. 
czego $^{19}$. Nie rządzi się więc określonymi prawami, również fizycznymi, raczej należy stwierdzić, że w zależności od dynamiki materii, prawa te moga obowiąywać tylko lokalnie ${ }^{20}$. Przyczynowość ciagle tworzyć się ma wraz z sama materia ${ }^{21}$. Prowizoryczny porządek w niej wprowadza nieodróżnialny od niej samej akt jej badania, nieodmienny z kolei od działania, w szczególności politycznego (zob. niżej). Jak to określa Barad, intraakcje powoduja sprawcze „cięcia” - prowizoryczne jedynie wyodrębnienie przedmiotów, aktów poznawczych i praktycznych, podmiotów poznających i działających jako wypadkową dynamizmu i witalności materii ${ }^{22}$.

Na gruncie nowego materializmu nie można jednak mówić o jakimś zewnętrznym, podmiotowym oddziaływaniu na materię, wydobywającym jej potencjalności. Akty sprawcze jawią się jako właściwe „składniki” materii (Barad posługuje się pojęciem agential realism ${ }^{23}$ ) o nieokreślonym „zasięgu” oddziaływania, a raczej tworzenia (podobne do „maszyn pragnienia” w koncepcji Deleuza) ${ }^{24}$. Sprawczość nie jest już uważana za cechę określonego podmiotu, sama stanowi bowiem intraakcję $e^{25}$, nie jest więc potencjalnością czy zespołem cech materii, lecz jej przygodnym stanem.

Tak pojęta materia obejmuje również kulturę, jednak nie w sensie jednostronnego determinowania określonych fenomenów kulturowych przez działające na nie czynniki fizyczne czy ekonomiczne. Na gruncie nowego materializmu materia nie jest uznawana za przyczynę istnienia i kształtu kultury, kierunek ten odrzuca dualizm, również materialistyczny $^{26}$. To, co błędnie, zdaniem nowych materialistek, było zaliczane tylko do natury lub tylko do kultury, należy do tego

${ }^{19}$ K. Barad, Meeting the Universe Halfway. Quantum Physics and the Entanglement of Matter and Meaning, Durham-London 2007, s. 236.

${ }^{20}$ K. Barad Posthumanist..., s. 826.

${ }^{21}$ Podobny postulat - odrzucenie koncepcji świata materialnego rządzonego obiektywnymi, niezmiennymi w czasie prawami i oddzielania na tej podstawie nauk przyrodniczych i społecznych formułuje również Immanuel Wallerstein, również w przypadku tego myśliciela ma to służyć uprawianiu nauki otwartej na projekty ideowo-polityczne nie wynikajace $\mathrm{w}$ sensie tradycyjnie pojętej przyczynowości $z$ aktualnego stanu wiedzy. I. Wallerstein, Koniec świata jaki znamy, Warszawa 2004, s. 192-203. Myśliciel ten nie zarysowuje jednak projektu ontologicznego.

${ }^{22}$ K. Barad, Posthumanist..., s. 815. W nowym materializmie pojawia się kontrowersja, czy można przyjąc sprawczość materii, czy raczej sprawczości intraakcji, to pierwsze ma sugerować jaką́s materialistyczną metafizykę (i powrót do idei podmiotowości). Zob. T. Lemke, New Materialisms..., s. 15-16.

${ }^{23}$ K. Barad, Posthumanist..., s. 826.

${ }^{24}$ Ibidem, s. 816. Materia stanowić ma przejściowo tylko „zamarzniętą sprawczość”. Ibidem, s. 822.

25 Ibidem, s. 826-827.

${ }^{26}$ Ibidem, s. 817-818. 
samego pola relacji. W tej, jak to określa Haraway, „naturo-kulturze” zaciera się granica między tym co fizyczne i tym co językowe, bytami ludzkimi i nieludzkimi, można powiedzieć, że ma miejsce, podobnie jak w przypadku elektronów, „splatanie”, trudne do wyjaśnienia $\mathrm{w}$ „tradycyjnych” kategoriach ${ }^{27}$.

Nowy materializm przywołuje takie tradycyjne kategorie jak podmiot, podmiotowość i sprawczość, nadając im specyficzne znaczenia. $Z$ „zewnętrznego", krytycznego punktu widzenia zabieg taki jawi się jako ich dekonstrukcja, w szczególności, jeśli na gruncie nowego materializmu pojawia się idea podmiotu ludzkiego, to w kontekście dażenia do ostatecznego przezwyciężenia antropocentryzmu. Poza tym taki podmiot jawi się wyłącznie jako składnik materii, nie bardziej uprzywilejowany ontologicznie niż inne jej sprawcze składniki, „bryła mięsa poruszana przez elektryczne fale pragnienia" ${ }^{28}$. Podmiot ludzki stanowić ma, co najwyżej, „szczątkowa” kategorię, którą przedstawiciele tego kierunku posługują się ze względów retorycznych, zgodnie $z$ postulatem unikania dualizmu i „poprzecznej” interpretacji zastanych idei. Kategoria ta nie przynosi jakichś samoistnych treści. Jeśli chciałoby się coś powiedzieć o jego cechach, to jawi się on jako Deleuzowski „podmiot nomadyczny” czyli, jak twierdzi Braidotti, podmiot, którego „istotę”, a nie brak stanowi nieokreśloność tożsamości, tak jak istota, a nie problemem tożsamości nomady jest brak identyfikacji $z$ jakimkolwiek miejscem ${ }^{29}$.

W tym miejscu pojawia sie pytanie o to - kto, w sensie politycznym, będzie dokonywał "cięć" ontologicznych, uruchamiał „maszyny pragnienia" i prowizorycznie definiował intraakcje. Nowy materializm kompatybilny $z$ innymi współczesnymi nurtami myśli politycznej stawiającymi sobie za cel gruntowna przebudowę człowieka i świata, w szczególności z ekologizmem. Nie chodzi oczywiście o ekologizm jako program zapewnienia człowiekowi dobrostanu dzięki poszanowaniu przyrody jako zasobu, lecz o ekologizm "głęboki”30, $z$ tym jednak zastrzeżeniem, że na gruncie nowego materializmu nieuzasadnione jest koncentrowanie się wyłącznie na materii ożywionej, jak

${ }^{27}$ Według Grosz relację między naturą i kultura obrazować ma wstęga Möbiusa. E. Grosz, Space, Time and Perversion: Essays on the Politics of Bodies, New York-London 1995, s. VII.

${ }^{28}$ R. Braidotti, Tetralogies, w: Deleuze and Feminist Theory, eds. I. Buchanan, C. Colebrook, Edinburgh 2000, s. 159.

${ }^{29}$ R. Braidotti, Poprzez nomadyzm, „Teksty Drugie: teoria literatury, krytyka, interpretacja”, 2007, nr 6 (108), s. 107-127.

${ }^{30}$ Zob. J. Kulasiewicz, Głęboka ekologia Arne Naessa, Dolina Wapienicy k. Bielska-Białej 1993. 
również uznawanie za wartość polityczną bytów o sprecyzowanych tożsamościach (Natury, Ziemi itd.). Nowy materializm, posługując się idea praw (pseudo) podmiotowych, zastrzega, że możliwość ich posiadania nie jest wyznaczona, tak jak np. w personizmie Petera Singera, jakimikolwiek cechami ich „posiadaczy”, maja być to prawa zwierząt, ale również roślin, przedmiotów nieożywionych, ekosystemów itd. ${ }^{31}$

Nie ma też sprzeczności między nowym materializmem a koncepcjami transhumanistycznymi, zakładającymi powstanie, dzięki rozwojowi techniki, istot rozumnych nie będacych, w sensie biologicznym, ludźmi, doskonalszych od człowieka w sensie poziomu inteligencji i możliwości działania ${ }^{32}$. W ten sposób na gruncie nowego materializmu możliwa staje się afirmacja wpływu techniki na życie. Akceptację technicyzacji życia współcześnie wyrażały już różne nurty ideowe, jej wyrazem było w szczególności hasło podejścia systemowego, a zwłaszcza systemów autopoetycznych. Jednak idea systemu nie tylko budzi negatywne skojarzenia w sensie etycznym i politycznym (jako przeciwstawienie społeczeństwa, świata życia itd.), ale i konotuje jednak pewne obiektywne prawa, mogące ograniczać polityczną zmianę. Nowy materializm posługuje się hasłem zwiększenia możliwości kontroli społecznej roli techniki dzięki ujawnieniu sprawczego charakteru materii, zarazem jednak uzasadnia rezygnację $z$ prób pełnego zapanowania nad nia. Wytwory techniki nie sa już uznawane za narzędzia realizacji celów człowieka, przypisuje się im, tak jak całej materii, przymiot sprawczości ${ }^{33}$. Konstatacja ta uzasadnia tezę o daremności prób pełnego panowania nad technologia i jej wytworami ${ }^{34}$. Zatarciu ulega granica nie tylko między człowiekiem a innymi istotami żywymi, ale również między istotami żywymi a maszynami ${ }^{35}$. Odrzucenie dualizmu natura - kultura uzasadniać ma tezę, że wytwory techniki posiadaja potencjał emancypacji. Nowoczesna nauka i technika ma

31 J.L. Smith, I, River?: New Materialism, Riparian Non-human Agency and the Scale of Democratic Reform, „Asia Pacific Viewpoint” 2017, t. 58, nr 1, s. 107.

32 K. Szymański, Transhumanizm: utopia czy ekstropia, „Studia nad Struktura i Rozwojem Pojęć Filozoficznych" 2015, nr XXVII, s. 159-175.

${ }_{33}$ T. Lemke, New Materialisms..., s. 4.

34 „Wiedza usytuowana wymaga, by przedmiot wiedzy zarysowany został jako aktor i sprawca, a nie ekran albo podstawa zasobów, nigdy wreszcie też jako niewolnik wobec pana, zamykającego ruch dialektyczny własnym, pojedynczym działaniem i autorstwem wiedzy "obiektywnej"”. D. Haraway, Wiedze usytuowane. Kwestia nauki w feminizmie i przywilej ograniczonej/częściowej perspektywy, www.ekologiasztuka.pl/think.tank.feministyczny [dostęp: 19 marca 2019], s. 24.

35 D. Haraway, A Cyborg Manifesto. Science, Technology, and Socialist-Feminism in the Late Twentieth Century, https://warwick.ac.uk [dostęp: 15 marca 2019], s. 11. 
uzmysławiać zatarcie granic nie tylko między natura i kultura, lecz również innymi powszechnie dotąd przyjętymi kategoriami postrzegania świata. Jak twierdzi Donna Haraway w słynnym Manifeście cybor-

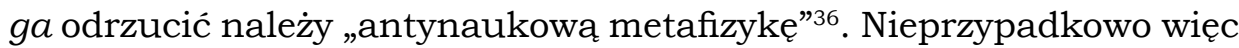
uznaje ona ideę cyborga za najpełniejszy wyraz przekraczania ustalonych kategorii ontologicznych i przypisuje jej funkcję symboliczna. Tożsamość cyborga ma być kluczem do zrozumienia tożsamości grup uciśnionych, takich jak „kolorowe kobiety”, hybrydalnych zarówno na skutek nieuprawnionego klasyfikowania przez ideologie władzy, jak i usprawiedliwionej, jej zdaniem, uniformizacji uzasadnianej walka o emancypację $e^{37}$. Technika, prowadzaca do swoistej cyborgizacji współczesnych ludzi, ma, jak uważa autorka, dwa oblicza - stanowi zarazem czynnik kontroli, jak i przekraczania granic i kodów kulturowych $^{38}$. Jest tak dlatego, że nauka „nowego materializmu” jawi się jako nieodróżnialna od polityki: „polityka i etyka stanowia podłoże dla walk i współzawodnictwa o to, co można zaliczyć jako wiedzę racjonalna, bez względu na to, czy chcemy, czy nie chcemy, przyznać, że chodzi o pole walki o różne projekty wiedzy w naukach ścisłych, przyrodniczych, społecznych i humanistycznych" ${ }^{\prime 3}$. Stwierdzić należy, że na gruncie nowego materializmu nie ma więc szczególnych etycznych czy politycznych przeszkód do tworzenia, dzięki technice lub połączeniu biologii i techniki, nowych gatunków istot żywych.

Podsumowaniem rozważań na temat politycznego aspektu rozumienia materii $\mathrm{w}$ nowym materializmie jest konkluzja, że o ile w postmodernizmie nastapiła dekonstrukcja ludzkiego podmiotu jako czynnika hamowania zmian polityczno-kulturowych ${ }^{40}$, to w nowym materializmie, $z$ tych samych przyczyn, następuje dekonstrukcja pojęcia przedmiotu, już nie przez wykazywanie, że stanowi on społeczna konstrukcje, lecz poprzez uznanie go za ciagłe samotworzenie. Idea rzeczywistości przedmiotowej, która na skutek wciąż odradzających się, dzięki znaczeniu techniki, ideom scjentystycznym, mogła stać się granica rewolucji kulturowej, a nawet punktem wyjścia dla odrodzenia jakiejś idei obiektywnego porządku rzeczy ${ }^{41}$, nie stawia już oporu

${ }^{36}$ Ibidem, s. 67.

37 Ibidem, s. 54.

38 Ibidem, s. 12-14.

39 D. Haraway, Wiedze..., s. 17.

40 A. Barut, Prawa człowieka jako dekonstrukcja symboliki prawno-politycznej społeczeństwa ponowoczesnego, Warszawa 2019, s. 109-119.

${ }^{41}$ O uzasadnianiu XIX-wiecznego politycznego tradycjonalizmu poprzez odwołania do haseł pozytywistycznych zob. A. Barut, Egotyzm, etyka, polityka. Myśl konserwatywna Maurycego Barrèsa, Kraków, 2009, s. 48-50. 
projektowi zmian politycznych, ponieważ sama materia jest zmiana polityczną. Jeśli użycie danego instrumentu badawczego zmienia nie wynik doświadczenia przyrodniczego, lecz przyrodę, to taki sam wynik może przynieść „użycie” idei politycznej, również stanowiącej rodzaj materii. Zaznaczyć trzeba, że nowy materializm, przynajmniej w jego obecnej postaci, nie głosi programu jawnego, centralnie zadekretowanego podporządkowania teorii naukowych programom ideologicznym (jak w sowieckiej nauce pod koniec okresu stalinowskiego), uzasadnia jednak bardziej rozproszone, politycznie motywowane "produkowanie" faktów i kryteriów naukowości.

Jako przykład politycznej (samo)kreacji materii można wskazać skonstruowanie, mówiąc językiem Latoura, „hybrydy” o szczególnym znaczeniu politycznym, czyli „globalnego ocieplenia”, które nie jest tylko zagadnieniem przyrodniczym, ale również społecznym, etycznym, obyczajowym oraz politycznym ${ }^{42}$.

\section{QUASI-OBIEKTYWIZM NOWEGO MATERIALIZMU}

O ile $\mathrm{w}$ postmodernizmie przez politykę była uwarunkowana przede wszystkim epistemologia, to w nowym materializmie następuje powiązanie polityki $z$ ontologia (stąd u Barad pojęcie onto-etyko-epistemologii ${ }^{43}$ ). Odwołania do pojęć nauk przyrodniczych, hasła realności i materialności mają szansę zwiększyć siłę oddziaływania ideologicznego, możliwe staje się uniknięcie zarzutu oderwania od rzeczywistości i relatywizmu, który pojawiał się w stosunku do konstruktywizmu postmodernistycznego. Nowy materializm pozwala współczesnej myśli lewicowej, a zwłaszcza feminizmowi legitymizować się jako ideologia oparta na podstawach obiektywnych.

Nowy materializm, poprzez uznanie podmiotu ludzkiego za część materii, ma swoiście „przywoływać do rzeczywistości” jednostki, które chciałyby widzieć w świecie jako konstrukcji kulturowej pole nieograniczonego spełniania pragnień i realizacji swobodnie wybra-

${ }^{42}$ Por. D. Coole, S. Frost, Introducing..., s. 16-17. Na gruncie „tradycyjnej” logiki nie sposób przesądzić o jego realności, w nauce formułuje się bowiem argumenty naukowe za i przeciw istnieniu efektu cieplarnianego. Nie sposób też, wracając do praktycznej mądrości czy „świata życia,” odwołać się do doświadczenia jednostkowego czy pamięci ponadpokoleniowej, ocena zmian klimatycznych przekracza bowiem te horyzonty. Zobiektywizować efekt cieplarniany można jednak na gruncie ideowopolitycznym, używając np., tak jak to czyni Latour (B. Latour, O kilku afektach zrodzonych z kapitalizmu, przel. M. Szalewicz, w: Smutek konkretu, Warszawa 2015, s. 200) pojęcia antropocenu. Tworzy w ten sposób badana rzeczywistość, dokonując ontologicznego (a ściślej mówiąc politycznego) cięcia, po którym efekt cieplarniany jawi się jako fakt niemożliwy do zakwestionowania.

${ }^{43}$ K. Barad, Meeting..., s. 185. 
nych projektów tożsamościowych. Stąd idea odpowiedzialności za materię (a ściślej mówiąc samoodpowiedzialności materii) ${ }^{44}$. Nowy materializm stawia postmodernizmowi zarzut zapoznawania obiektywności warunków walki politycznej. Postmodernistyczna ironia i (de)konstruktywizm mają kierować swe ostrze, przynajmniej potencjalnie, nie tylko wobec opresywnych wzorców moralnych i obyczajowych, ale również wobec postępowych ideologii.

W koncepcji Haraway przyjęcie „ucieleśnionego” punktu widzenia ma przeciwdziałać zarówno esencjalizmowi tożsamościowemu, jak i relatywizmowi koncepcji etycznych i politycznych. „Wiedza usytuowana", jak to określa Haraway, nakazuje polityczna powagę, unikanie relatywizmu mającego być druga strona esencjalizmu. Jedna i druga postawa zakłada bowiem, według autorki, istnienie raz na zawsze ustalonych tożsamości, w pierwszym przypadku będących przedmiotem lekceważenia w drugim - politycznej afirmacji ${ }^{45}$. Jak pisze „Potrzeba nam silnych nowoczesnych teorii krytycznych, odnoszacych się do produkcji znaczeń i ciał - nie żeby zaprzeczać ich istnieniu, ale by zacząć żyć wśród znaczeń i ciał mających jakąś szansę na przyszłość"46. Taka obiektywność nie oznacza jednak odpowiedniości sadu do jakiegoś stanu rzeczy, lecz odpowiedzialność polityczna za kształtowanie (się) materii, za dokonywanie ontologicznych cięć, wytwarzajacych intraakcje i produkujacych tymczasowe przedmioty, za wytwarzanie tego co „obiektywne”47. Ostatecznie więc obiektywność $\mathrm{w}$ nowym materializmie polega na samouświadomieniu znaczenia walki politycznej.

Polityka oparta na „materialnych” przesłankach zmierzać będzie, jak uważaja rzeczniczki nowego materializmu, do gruntownej przebudowy świata społecznego, istota materii ma być bowiem dynamika i ciagła zmiana. Przykładem „korpor[e]alny” feminizm Elisabeth Grosz, (jak go sama określa). Autorka ta sięga do Darwinowskiej koncepcji ewolucji, z której czerpie ideę „historycznego” aspektu przyrody oraz samorzutnych, nieplanowych zmian dokonujacych się w materii. Grosz interpretuje Darwinowska kategorię doboru naturalnego poprzez pryzmat pojawiania się przypadkowych, a zarazem naddat-

${ }^{44}$ Wyrazem tego odwołanie się Barad do filozofii dialogu Émmanuela Lévinasa. Ibidem, s. 391-396.

45, „...] «równość" wszystkich pozycji oznacza odmowę przyjęcia odpowiedzialności i podjęcia krytycznego badania. Relatywizm stanowi w ideologiach obiektywności doskonałe odzwierciedlenie totalizacji”. D. Haraway Wiedze..., s. 14.

46 Ibidem, s. 7.

47 K. Barad, Meeting..., s. 361, 390-391. 
kowych, $z$ perspektywy szans na przeżycie konkretnych osobników, zmian wpływających na atrakcyjność seksualna, a przez to możliwość przekazania cech potomstwu. Według Grosz dobór partnerów i atrakcyjność seksualna (czyli określone fakty biologiczne), uwarunkowane wysoce zróżnicowanymi czynnikami, nie przekładającymi się bezpośrednio na możliwość zdobycia pożywienia, ataku czy ucieczki stanowi wyraz i ugruntowanie wszechobecnej w materii i ,istotowej” dla niej różnicy, co uzasadnia $z$ kolei ideę niezdeterminowania tożsamości, w szczególności liczby płci ${ }^{48}$. Na gruncie takiej koncepcji umocowanie faktualne, „biologiczne”, staje się więc uzasadnieniem twierdzeń o niegraniczonych możliwości przekształcenia polityczno-kulturowego. W tej perspektywie materia uzasadnia określone postulaty polityczne, a przy tym sama jest dopiero definiowana w politycznej praktyce.

Przyjęcie ucieleśnionego punktu widzenia ma pozwalać na uniknięcie „niebezpieczeństwa” zrelatywizowania przez postmodernizm doświadczenia wynikającego, w autointerpretacji grup uciśnionych, z ich wyposażenie materialnego (rasy, płci, niepełnosprawności itp.) i odeprzeć zarzut jego zapoznawania. Nie uzasadnia jednak żadnego „esencjalizmu” tożsamościowego, również takiego, który stanowiłby wyraz ich świadomości. Przykładem nowomaterialistycznego podejścia do problemu politycznego reprezentowania tożsamości są rozważania Haraway o relacji pojęć sex-gender. Jak pisze „utrata autorytarnych biologicznych opowieści o płci [sex], które wywoływały twórcze napięcie w zestawieniu ze swym binarnym dopełnieniem, gender, oznacza chyba stratę zbyt dotkliwa" ${ }^{49}$, a zarazem podkreśla, że nowy materializm nie oznacza „absolutyzacji” takich punktów widzenia czy też bezwarunkowej akceptacji żądań wysuwanych przez grupy konstytuujące w oparciu o nie swe tożsamości, lecz wręcz przeciwnie, ich transformację $e^{50}$.

Tożsamość, na etapie poprzedzającym walkę polityczną, jawi się ostatecznie jako przypadkowa (wyraża sprawcza przypadkowość materii), $z$ tego punktu widzenia bycie hetero czy homoseksualista nie ma być skutkiem działania czynników biologicznych, kulturowych

${ }^{48}$ E Grosz, Darwin i gatunek ludzki, przeł. M. Rogowska-Stangret, „Przegląd Filozoficzno-Literacki” 2011, nr 4; por. M. Rogowska-Stangret, Ciało poza Człowiekiem, czyli Ciało Wyemancypowane $w$ ujęciu Elizabeth Grosz, „Interalia. Pismo poświęcone studiom queer” 2012, nr 7, http://www.interalia.org.pl/ [dostęp: 3 kwietnia 2019].

49 D. Haraway, Wiedze..., s. 23, 19.

50 Ibidem, s. 16. „Feministyczne ucieleśnienie nie przekłada się więc na ustalone umiejscowienie w urzeczowionym ciele [...] obiektywność nie może oznaczać widzenia ustalonego [fixed], skoro to, co liczy się jako obiekt, jednocześnie okazuje się być tematem historii”. Ibidem, s. 18-19. 
ani nawet, co szczególnie istotne, określonej decyzji jednostki co do jej tożsamości, lecz sposobem wyrażania siebie, przekraczającym te „rzekome” uwarunkowania (w tym również to, co uznaje się za świadomość i wolna wolę) ${ }^{51}$. Hasło realności tożsamości pojawia się dopiero $\mathrm{w}$ stadium stricte ideologicznym. Zdaniem jednego $\mathrm{z}$ rzeczników nowego materializmu ma on służyć odnalezieniu przez Boliwijczyków prowadzacych walkę $z$ konserwatywnym rządem ich własnej materialności jako Indian (dążących do niej, jak pisze autor, niczym duchy poszukujące ciał). Gdy w sferze politycznej samoidentyfikuja się oni jako rdzenni mieszkańcy Boliwii, spotykają się z zarzutem (niesłusznym, zdaniem autora), że są w rzeczywistości, biologicznie, Metysami, podobnie jak ogromna większość mieszkańców tego regionu ${ }^{52}$.

O konstrukcji tożsamości decyduje więc polityczność samej materii. Seksualność nie odzwierciedla jakiejś obiektywnej rzeczywistości, w tym materialnej, niemniej jej (nowo)materialność nadaje znaczenie żądaniom opartym na idei (opresjonowanej) płci. Znaczenie takich kategorii jako płeć ujawniać się ma w relacji do innych kategorii tego typu, jak rasa czy klasa, oraz wykluczenia, które moga one powodować. Ma to pozwalać na rozwiazanie problemu reprezentacji kobiecej materialności w prawie, postrzeganym często w feminizmie jako konstrukcja obca temu uwarunkowaniu ${ }^{53}$. „Zniesiony” ma zostać dylemat: czy dążyć do tego, by prawo „wiernie” oddawało kobieca tożsamość (w możliwość osiagnięcia tego celu wątpi tzw. feminizm różnicy), czy też kwestia odzwierciedlenia tej tożsamości w ogóle nie ma znaczenia, skoro tożsamość, tak samo zreszta jak prawo, jest tylko konstrukcja kulturowa, jak głosi postmodernizm (a raczej jego nowomaterialistyczna wykładnia - przyp. A.B.). Sama reprezentacja staje się bowiem kategoria relacyjna, wyznaczona przez dynamikę reprezentowanej materii ${ }^{54}$. Również idea rasy, podobnie jak płci, ma mieć tak rozumiana materialna realność, nadająca znaczenie walce $z$ rasizmem, a zarazem stanowić kategorię tak samo jak materia dynamiczną i relacyjna, nieuzasadniającą binarnych podziałów np. na rasę biała i czarna, nowy

51 E. Grosz, Materialism, Feminism and Freedom, w: New Materialism. Ontology, Agency and Politics, eds. D. Coole, S. Frost, Durham-London 2010, s. 153.

52 O. Guardiola-Rivera, Return of the Fetish: A Plea for a New Materialism, „Law Critique" 2007, nr 18, s. 276-281.

53 A. Barut, Prawa..., s. 162-164.

54 J. Conaghan, Feminism, Law and Materialism: Reclaiming the 'Tainted'Realm, https:// www.researchgate.net/publication/272620623_Feminism_law_and_materialism_reclaiming_the_tainted_realm' [dostęp: 26 marca 2019], s. 47. O prawach podmiotowych w feminizmie w kontekście konceptualizacji kobiecej tożsamości por. A. Barut, Prawa..., s. 155-160 . 
materializm uzasadnia więc ideę nieskończonej wielości ras ${ }^{55}$. O znaczeniu rasy także decyduja, ostatecznie, względy polityczne.

Należy postawić pytanie, czy taka emfaza na materialność i cielesność nie oznacza, podobnie jak postmodernistyczna emfaza na język, jako akt swoistej „złej wiary”, ich dekonstrukcji, a przez to ostatecznego odcieleśnienia podmiotu politycznego i prawnego. Jak trafnie zauważa jedna $z$ przedstawicielek nowego materializmu prowadzić on może do odebrania znaczenia politycznego koncepcjom odwołującym się do roli czynników biologicznych ${ }^{56}$. Płeć (biologiczna), która wcześniej, jak twierdzą feministki, determinowała podział na uciskających i uciskanych (chociaż jej znaczenia miało być skrywane przez opresywne wzorce kulturowe), po stadium ujawnienia przez feminizm jej politycznego znaczenia może, pochłonięta przez wszechobecną różnicę, zniknąc jako punkt odniesienia dla programów politycznych i projektów ustawodawczych. Gdy wszystko stanie się „materia”, a przez to „różnica”, pozostaja tylko przygodne stany „materii” - przejściowe stany (nie)świadomości jednostkowej, tymczasowe konstelacje polityczne, hasła ideologiczne itp. Powoływanie się, dla uzasadnienia postulatów ustawodawczych na różnice je przekraczające, w tym zróżnicowanie potrzeb, możliwości i zagrożeń wynikających $z$ „binarnie” pojętego zróżnicowania płciowego, przestaje mieć sens.

\section{ODEJŚCIE OD PARADYGMATU PRAW CZŁOWIEKA}

Skoro nowy materializm ostatecznie rezygnuje $z$ idei podmiotu ludzkiego jako uprzywilejowanej kategorii poznawczej, etycznej i politycznej, a zarazem kładzie nacisk na obiektywność ideologii uzasadnianych obiektywnościa materii, na jego gruncie traci sens koncentrowanie się na jednostce i jej prawach.

Głoszona przez Haraway idea cyborga ma zaprzeczać mitom fundacyjnym Zachodu o wyłanianiu się tożsamości poprzez różnicowanie się niezróżnicowanej jedności oraz o powrocie do natury i stanu spełnienia ${ }^{57}$. Według Rosi Braidotti etyka nowego materializmu odrzuca zasadę wzajemności (na której opierają się, jej zdaniem, etyki przednowoczesne i nowoczesne, etyka postmodernistyczna, a nawet etyka inności), etyka ta ma promować afirmację wszelkich aspektów materii

55 T. Leppänen, Race, https://newmaterialism.eu/almanac/r/race.html [dostęp: 29 marca 2019].

56 Autorka ta ocenia tę tendencję pozytywnie. M. Rogowska-Stangret, Ciało..., s. 9-10.

57 D. Haraway, A Cyborg..., s. 8-9. 
w ich zróżnicowaniu i wzajemnym powiązaniu ${ }^{58}$. Nowomaterialistyczna, inspirowana filozofia Spinozy, perspektywa ma uzasadniać odrzucenie idei uznania jako kluczowej kategorii filozoficzno-politycznej59, czego wyrazem używane przez Grosz hasło „polityki niezauważalności" (politics of imperceptibility) ${ }^{60}$.

Paradygmat praw podmiotowych przestaje być decydujacy. Postawienie człowieka ontologicznie nie wyżej nie tylko od zwierząt czy roślin, lecz również przedmiotów uzasadnia odebranie znaczenia idei praw człowieka. Jak to ujmuje Elisabeth Grosz, idea podmiotowości opiera się na postulatach autonomii, sprawczości i wolności, rozumianych jako wolność od zewnętrznych ograniczen, wolność podmiotu oddzielonego od otoczenia. Na takim rozumieniu podmiotu opierała się, jak twierdzi, idea praw podmiotowych. Koncepcji tej Grosz przeciwstawia witalistyczna ideę wolności, głoszona, jak twierdzi, przez presokratyków, Nietzschego i Bergsona, rozumiana jako realizacja potencjalności wszelkich aspektów materii. Według Grosz feminizm powinien przyjąć ideę wolności rozumianej nie jako cecha świadomości, lecz jako działanie ciała, autonomia wynikajacca $z$ jego niezdeterminowania i ciagłej możliwości zmiany, jej warunkiem nie jest więc posiadania przez jednostkę określonej przestrzeni wolności czy uzyskiwanie jakiegoś zestawu świadczeń. $Z$ tej perspektywy wolność nie ma być cecha czy władzą podmiotu, lecz procesu kształtowania się materii. Jest to więc stan niemożliwy do apriorycznego określenia, a nie prawo podmiotowe ${ }^{61}$. Nowy materializm różni się $\mathrm{w}$ tym aspekcie od postmodernizmu. Postmodernizm dokonał wprawdzie dekonstrukcji podmiotu - nowy materializm stanowi uwieńczenie tego zabiegu - zarazem jednak, czy to w koncepcji Richarda Rorty'ego, czy w inspirowanym poststrukturalizmem postmarksizmie zachowywał hasło podmiotu i jego praw jako użyteczne ideologiczne narzędzie, „pustą znacząca”, pod którą można podstawiać rozmaite polityczne postulaty ${ }^{62}$. W dobie nowego materializmu nawet tak szczątkowa treść idei podmiotu okazuje się nieadekwatna.

Pełne odejście od przyznawania jednostce ludzkiej szczególnej wartości, a zatem i określonych praw wyraża się w odebraniu znaczenia

58 R. Braidotti, The Politics of „Life Itself” and New Ways of Dying, w: New Materialism. Ontology, Agency and Politics, eds. D. Coole, S. Frost, Durham-London 2010, s. 214.

59 M. Janik, Benedykt Spinoza: ciało filozofii i polityka przekształcenia w: Feministyczne nowe materializmy..., s. 155.

60 E. Grosz, A Politics of Imperceptibility: A Response to ,Anti-racism, Multiculturalism and the Ethics of Identification', „Philosophy and Social Criticism” 2002, nr 28 (4), s. 463-472.

61 E. Grosz, Materialism..., s. 142-148, 151-153.

62 A. Barut, Prawa..., s. 113-114. 
prawa do życia. Znamienne sa rozważania Braidotti. Dla autorki tej, podobnie jak dla Grosz, wolność przestaje być istotna wartościa etyczną i polityczna ${ }^{63}$. O ile jednak w wyżej wskazanych wypowiedziach Grosz odrzucenie wolności wiązało się $z$ witalizmem i $z$ afirmacja połączenia jednostki $z$ materia, to u Braidotti chodzi raczej o pochłonięcie jednostki przez materię. Według Braidotti nowy materializm uzasadnia odrzucenie „narcystycznego” koncentrowania się na życiu indywidualnym. Braidotti chce, jak twierdzi, odejść od ugruntowanego w myśli zachodniej skupianiu się na bios - życiu ujętym w reguły, podporządkowanemu rozumowi, w kierunku afirmacji zoe - życia dotychczas identyfikowanego $z$ egzystencją zwierzęca, co, jak sama wskazuje, jest nieludzkie i obsceniczne. Braidtotti stwierdza, że odwołuje się do Agambenowskiej idei „nagiego życia." ${ }^{4}$. Jednak, co należy zauważyć, u Giorga Agambena zoe jako wytwór podporządkowującej, klasyfikujaccej i właczającej poprzez wyłączenie władzy (obraz zoe jako oddzielonego od bios oddawać miał istotę władzy) nie było samo $\mathrm{w}$ sobie afirmowane. Według tego autora ten, kto jest sprowadzony do zoe: „święty człowiek”, kozioł ofiarny itd., nie jest nim z własnej woli ani we własnym interesie ${ }^{65}$. Inaczej jest u Braidotti. „Podmiot nomadyczny" wskazywany przez nią już w jej wcześniejszych (przednowomaterialistycznych) wypowiedziach jako ideał podmiotowości, zidentyfikowany teraz zostaje $z$ materia i zoe. Cechować ma go taki rodzaj upodmiotowienia, który „ostatecznie, prowadzi do stania się niedostrzegalnym, do zgaśnięcia, śmierć jest kolejną sekwencją czasowa” ${ }^{66}$. Jak twierdzi „ten nieantropocentryczny pogląd wyraża zarazem głęboka miłość do Życia jako kosmicznej siły, jak i pragnienie zdepersonalizowania subiektywnego życia - i - śmierci”, „To po prostu jakiejś życie, nie moje życie. Życie we „mnie” nie odpowiada na moje imię, ja po prostu przemija”67. Skoncentrowaniu się na Życiu ( $\mathrm{z}$ wielkiej litery) odpowiada więc skoncentrowaniu się na śmierci. Braidotti także nie odrzuca tylko jednostkowego, ludzkiego prawa do życia, lecz prawa podmiotowe w ogóle. Nie zaleca wyłącznie odejścia od (jak sama wskazuje, powszechnego) koncentrowania się na posiadanych rzekomo prawach, ale również rezerwę wobec pragnienia kompensacji

63 „Człowieczeństwo nie wywodzi się z wolności, lecz raczej wolność uzyskuje się dzięki świadomości ograniczeń” (materialnych). R. Braidotti, The Politics..., s. 215.

${ }^{64}$ Ibidem, s. 211-212.

65 G. Agamben, Homo sacer: suwerenna władza i nagie życie, przeł. M. Salwa, Warszawa, 2008.

66 Ibidem, s. 207-208.

67 Ibidem, s. 210. 
krzywd oraz współczucia wobec bólu ${ }^{68}$. Nie odrzuca wyłącznie postulatu polepszania bytu ludzkiego, jej celem przestaje być jakkolwiek pojęty ludzki dobrostan. Jak pisze, dostrzec należy, że „ból ma siłę tworzącą", zaleca, jak wskazuje, Nietzscheańską etykę odwrócenia negatywności, amor fati ${ }^{69}$. Temu rozpłynięciu się w relacjach tworzących materię sprzyjać ma „testowanie” i przekraczanie granic zoe (jednostki zidentyfikowanej $z$ materia). Pogrążenie w materii i otwartość na ból zawierać ma w sobie szansę na transgresję, jest to, jak wprost stwierdza, cena, która warto zapłacić. Przekłada się to na program działania politycznego. Jak wskazuje Braidotti należy afirmować eksperyment i zmianę społeczna, porzucić ideę zmierzchu ideologii ${ }^{70}$.

Polityka nie powinna więc, jak przyjmowała Hanah Arendt, opierać się na paradygmacie prezentowania indywidualnej, ludzkiej wyjątkowości w przestrzeni publicznej ${ }^{71}$. Nowomaterialistyczna polis przestaje być dziedzina spraw ludzkich. Formułowane sa hasła „demokracji przedmiotów”72 i „parlamentu rzeczy”73. W wypowiedziach rzeczniczek nowego materializmu wskazuje się na nowe perspektywy, które ma otwierać taka polityka. Jak podkreślaja, upodmiotowienie materii pozwoli bardziej adekwatnie spojrzeć na rolę czynników materialnych we współczesnym świecie, rozstać się ze złudnymi nadziejami na pełną kontrolę cyrkulacji zanieczyszczeń czy odpadów, na projektowania zmian środowiska mających je rzekomo chronić ${ }^{74}$. Transgresyjny charakter polityki nowego materializmu ma jednak sięgać istoty polityczności i sposobu legitymizacji współczesnego państwa. Jane Bennett odwołuje się do postmarksisty Jacquesa Rancière'a i jego idei demosu jako wyrazu „nadmiaru”. Według tego autora demos to ani konkretna zbiorowość, ani jej większość, ani nawet uciśniona mniejszość, lecz ideowy „naddatek” idei demokracji w stosunku do jej praktyki, motor zmian ideowo-politycznych ${ }^{75}$. Zdaniem Bennett, Rancière nie dostrze-

68 Ibidem, s. 212-213. Twierdzi, że skupienie się na zoe pozwala na depersonalizację, czyli na zrozumienie bezsensu ( $z$ indywidualnego punktu widzenia) zarówno cierpienia, jak i kompensacji, a zatem i prawa do kompensacji. Ibidem, s. 213.

69 Ibidem, s. 214.

70 Ibidem, s. 209-211.

71 T. Lemke, New Materialisms..., s. 16. Na gruncie nowomaterialistycznego odczytania koncepcji Spinozy jako politycznie relewantny element materii jawi się relacja, a nie „substancja”. M. Janik, Benedykt..., s. 157-159.

72 L. Bryant, The Democracy of Objects, Ann Arbor 2011.

73 B. Latour, Nigdy..., s. 200-204.

74 Wyrazem nowomaterialistycznego podejścia w socjologii jest np. ujęcie najnowszej historii Egiptu przez pryzmat historii komara. T. Mitchell, Czy komar może przemówić? w: Kultura nie-ludzka, red. A. Kil, J. Małczyński, D. Wolska, Wrocław 2015, s. 17-58.

75 O roli koncepcji Rancière'a w dekonstrukcji podmiotu demokracji zob. A. Barut, Prawa..., s. 147, 264-265. 
gał jednak, że czynnikiem twórczej destabilizacji może być właśnie upodmiotowiona materia, na którą należy rozszerzyć zasięg demosu ${ }^{76}$. Polityka taka nie będzie polityka prowadzona w interesie człowieka, chyba że postrzeganego jako składnik materii. $Z$ perspektywy nowomaterialistyczna polityka jawi się nie jako sposób realizacji ludzkich pragnień, spychanych dotąd na margines na skutek przyjmowania wyłączającej idei podmiotu, lecz właśnie czynnik ich ograniczania. W nowym materializmie ujawnia się również, oprócz afirmacji aktywizmu politycznego, postulat powściagnięcia żądań i dążenia do uznania, przy tym bez przyjęcia jakiejkolwiek teleologicznej koncepcji człowieczeństwa ${ }^{77}$. Powraca idea praw, ale już nie jako praw człowieka, lecz praw wszelkich przejawów materii (np. rzek) ${ }^{78}$. Sprzyjać ma temu dokonujące się współcześnie odejście od ich jakiegokolwiek prawno -naturalnego umocowania i uznanie praw człowieka za sposoby radzenia sobie $z$ problemami, ocenianymi $\mathrm{w}$ danej sytuacji negatywnie $z$ punktu widzenia etycznego lub politycznego ${ }^{79}$.

Oceniając te tendencje, należy stwierdzić, że nowy materializm odzwierciedla w pewnym stopniu słuszną rezerwę wobec oświeceniowych i postoświeceniowych planów pełnej kontroli nad środowiskiem, obecnie głoszonych w imię jego ochrony. Rezerwa ta towarzyszyła „oświeceniu" od samego początku i wyraziła się w takich nurtach ideowych, jak romantyzm, postromantyzm, witalizm i heideggeryzm. Jednak kierunki te albo zachowywały ideę ludzkiego podmiotu, albo wpisywały „życie”, Dasein itd., w pewne ramy pojęciowe (ewolucja twórcza, „troska”) uniemożliwiające polityczną afirmację każdego $z$ ich przejawów. $\mathrm{Na}$ gruncie nowego materializmu takich pozapolitycznych kryteriów nie ma, a w każdym razie traca one znaczenie. Pojawia się pytanie, co będzie celem polityki nowomaterialistycznej - jeśli ma być nim „branie na poważnie" samoistności materii, to czy ostatecznie nie będzie ona jej (samo)administrowaniem? Jeśli polityka nie ma być walką o uzna-

76 Czyli „martwe szczury, kapsle od butelek, gadżety, ogien, elektryczność”. J. Bennett, Vibrant Matter. A Political Ecology of Things, Durham-London 2010, s. 104-107, cytat s. 107.

77 Znamienna jest wypowiedź Hanny Meißner: „Nowe materializmy stawiaja przed nami wyzwanie ponownego przemyślenia „klasycznych” pojęć transformacji, polityki i emancypacyjnej sprawczości. W szczególności sa zakwestionowaniem antropocentrycznej pychy zawartej w pojmowaniu tego, co polityczne jako szczytu ludzkiej wyjatkowości: zdolności transformowania i kształtowania (społecznego) świata. Ta ważna perspektywa krytyczna wyłania się w historycznym momencie, który domaga się odnowienia radykalnych społecznych alternatyw w odpowiedzi na kryzys ekonomiczny, społeczny i ekologiczny". H. Meißner, Wywiad..., s. 263.

78 J.L. Smith, I, River...

79 Ibidem, s. 100. Autor ten odwołuje się do koncepcji Jacka Donnelly'ego, szczególnie istotnej dla ponowoczesnego rozumienia praw człowieka. A. Barut, Prawa..., s. 132-133, 141. 
nie ludzkiej podmiotowości, to czy nie stanie się techniką rządzenia, niemożliwa do ujęcia w postaci przewidywalnych (przez rządzonych) reguł ogólnych, zarządzeniem rzekomo nieprzewidywalna materia, polegającym na arbitralnych „cięciach” polityczno-prawnych. Nawet zdaniem przedstawicielek myśli lewicowo-liberalnej, $\mathrm{w}$ tym również rzeczniczek nowego materializmu, kierunek ten, ze swoja pokora wobec techniki oraz odrzuceniem antropocentryzmu i specyficznie ludzkiej sprawczości może jawić się jako kolejna ideologia końca historii, prowadzaca do afirmacji neoliberalizmu i technokracji ${ }^{80}$, a koherentny $z$ nowym materializmem transhumanizmu uzasadniać powrót do neoliberalnego elitaryzmu ${ }^{81}$.

Ideowopolityczne znaczenie nowego materializmu wyraża się również w możliwości legitymizacji społeczeństwa sfragmentaryzowanego kulturowo, w którym władza polityczna ogranicza się jedynie do zwalczania zachowań bezpośrednio w nią wymierzonych. Na gruncie nowego materializmu możliwe jest polityczne i prawne pogodzenie się $z$ kulturami fundamentalistycznymi, pojmowanymi na jego gruncie jako swoista „materia” - czynnik niemożliwy do asymilacji nawet w ramach społeczeństwa wielokulturowego. Sprzyja temu uznawanie na gruncie teorii aktora sieciowego ontologicznej realności bytów pozaludzkich obdarzanych czcia religijna ${ }^{82}$. W ślad za tym, jeden $z$ nowomaterialistycznych autorów wzywa do uznania politycznej i prawnej sprawczości fetyszów - ubóstwionych przedmiotów kultu Voo Doo. Ich bytowa samoistność ujmuje w schemacie Heglowsko-Marksowskim: rzeczy te były (sa) obdarzone miłościa przez wyznawców, a zarazem przedmiotem strachu ze strony białych, w ten sposób, „alienując się”, obiektywizują się, a przez to upodmiotowiaja. Nie można więc „redukować" ich do symboli. Takie ujęcie umożliwiać ma, zdaniem autora, zrozumienie specyfiki znaczenia rzeczy w kultach religijnych dzisiejszych

80 A.Bielik-Robson, Wylewanie dziecka z kapiela, https://www.krytykapolityczna.pl/ felietony/20140917/wylewanie-dziecka-z-kapiela [dostęp: 16 kwietnia 2019]; H. Meißner, Wywiad..., s. 264-265.

81 S. Schmitz, Wywiad [bez tytułu], w: Feministyczne nowe materializmy..., s. 274-275. Jak pisze Diana Coole: „Widzę niebezpieczeństwo, że nacisk, jaki kłada nowe materialistki na ożywioną materię, może przeceniać mobilność i płynność kosztem zakrzepłej, spęczniałej materii, podobnie jak czynił to strukturalizm. Ważne jest, żeby krytyczna myślicielka rozpoznała, gdzie przepływy sa krępowane przez interesy i gdzie reprodukuje się strukturalne logiki bez większej fundamentalnej zmiany". D. Coole, Wywiad [bez tytułu], w: Feministyczne nowe materializmy..., s. 253-254.

82 Ontologiczna realność „bogów” jako quasi-obiektów przyjmuje Latour, zwalczając konstruktywistyczne rozumienie religii. Zaznacza przy tym, że: „Quasi-obiekty sa o wiele bardziej społeczne, o wiele bardziej skonstruowane, o wiele bardziej kolektywne niż "twarde" części natury, lecz w żadnym razie nie są arbitralnymi naczyniami dla gotowego społeczeństwa”. B. Latour, Nigdy..., s. 76-82, cytat s. 81. 
wielokulturowych społeczeństw, pozwala np. właściwie ująć specyfikę chust muzułmańskich czy wizerunków Mahometa ${ }^{83}$. Nowy materializm umożliwiać ma też uznanie polityczno-prawne religijnego immanentyzmu i animizmu ${ }^{84}$. Wywody te można skomentować w ten sposób, że w przypadku kultur fundamentalistycznych - „materii” jawnie opornej - nowy materializm rezygnuje $z$ wyżej zarysowanej idei uznawania, ale i przepracowywania partykularnych punktów widzenia.

\section{ZAKOŃCZENIE}

Ramy niniejszego artykułu uniemożliwiają rozważenie nowego materializmu jako programu poznawczego. Można jednak przyjąć, że np. na gruncie psychologii uzasadnia on zerwania $z$ dualizmem ciało umysł, a na gruncie teologii - panteizm. Interesujaca kwestia byłoby rozważanie możliwości zastosowania nowego materializmu w naukach prawnych, wydaje się, że uzaadniałby on rozumienie prawa pozytywnego jako quasi-obiektywnej materii, swoiście nadjednostkowej, a przy tym niemożliwej do ujęcia w związkach przyczynowo-skutkowych, co mogłoby posłużyć do jego legitymizacji w obliczu postępującej niepewności prawnej zarówno na poziomie legislacyjnym, jak i orzeczniczym ${ }^{85}$. W dziedzinie nauk społecznych nowy materializm kompatybilny jest ze wskazanym przez Immanuela Wallersteina postulatem odrzucenia zarówno rzekomo uniwersalnego, „baconowsko-newtonowskiego" modelu nauki, a $z$ drugiej - podziału na nauki nomotetyczne i idiograficzne oraz wyodrębnianiem na tej podstawie nauk przyrodniczych i zorientowanych humanistycznie nauk społecznych. Taki program naukowy, wprowadzajacy do nauk przyrodniczych zorientowanie na wartości, musiałby zapewne zrezygnować z postulatu nauki wertefrei. Na przykładzie koncepcji Wallersteina widać, że rezygnacja $z$ modelu "baconowsko-newtonowskiego" na rzecz modelu, jak to określa, „narracyjnego” uzasadnia uprawianie nauki otwartej na projekty ideowopolityczne nie wynikające, w sensie tradycyjnie pojętej przyczynowości, $z$ aktualnego stanu wiedzy ${ }^{86}$.

Wallerstein nie zarysowuje jednak projektu ontologicznego, czyni to nowy materializm, zwiększając, przynajmniej potencjalnie, siłę

83 O. Guardiola-Rivera, Return..., s. 276.

84 J.L. Smith, I, River..., s. 109.

85 O tych zjawiskach zob. np. L. Morawski, Główne problemy współczesnej filozofii prawa. Prawo w toku przemian, Warszawa 1999, s. 42-51.

86 I. Wallerstein, Koniec świata jaki znamy, Warszawa 2004, s. 192-203. 
oddziaływania ideowopolitycznego. Konstytutywna dla nowego materializmu idea sprawczej materii ma wyrażać niemożność dowolnego konstruowania świata pozaludzkiego. Zarazem zaprzeczajac, by człowiek posiadał statusu ontologiczny wyższy nie tylko od innych istot żywych, lecz również przedmiotów materialnych, nowy materializm stanowi ostateczne odejście od jakkolwiek pojętego humanizmu. Częścia „materii” mają być również procesy polityczne, w których materia „sama” decyduje o tym, co jest obiektywne. Nowy materializm jawi się w ten sposób jako odmiana Spinozjańskiego monizmu, nawiąuje również do materializmu dialektycznego Fryderyka Engelsa $z$ jego rozumieniem materii jako samoistnego przechodzenia przeciwieństw w nowa jakość, jak również z praktycystycznym kryterium prawdy. Kwestia ta ma istotne znaczenie $\mathrm{w}$ interpretacji nowego materializmu jako kierunku myśli politycznej, związki z „klasycznym” marksizmem potwierdzaja tezę o jego funkcji jako aktualnego odzwierciedlenia świadomości lewicowej.

Nowy materializm wydaje się być ideologicznie użyteczny w walce o zmiany polityczno-kulturowe, dotąd prowadzone głównie pod hasłami poststrukturalistycznego marksizmu. Politycznie obiektywne, a zarazem politycznie ukształtowane $z$ jego perspektywy sa takie kategorie jak opresjonowana mniejszość rasowa czy płciowa, co ma być antidotum na ich demitologizację dokonywaną również z pozycji konserwatywnych. Nowy materializm oznacza ostateczne odrzucenie idei politycznie relewantnej tożsamości jednostkowej, której nie gwarantuje już nie tylko umocowanie ontologiczne czy samoświadomość epistemologiczna i etyczna, lecz również cechy materialne. Można to skomentować $\mathrm{w}$ ten sposób, że $\mathrm{z}$ punktu widzenia koncepcji Agambena czasy, w których zrealizuja się postulaty nowego materializmu, będą czasami mesjańskimi, gdy różnicom odebrana zostanie moc opresyjna, a $z$ punktu widzenia psychoanalizy Pierre'a Legendre'a - czasami zaniku człowieczeństwa spowodowanego odrzuceniem tego, co stanowi warunek jego konstytucji, czyli odróżnienia się od wszechogarniajacej materii, czasami totalitarnej dosłowności ${ }^{87}$. Nowy materializm pozwala też ideologicznie asymilować obecność kultur fundamentalistycznych, odrzucających wartości świata zachodniego, a przy tym użytecznych dla ich dekonstrukcji. Jawia się one jako swoista „materia”, niemożliwa do przekształcenia i dlatego zasługujaca na polityczne uznanie. Zarazem, ostateczne odrzucenie idei ludz-

87 Zob. A. Barut, Prawo jako konstytuowanie człowieczeństwa. Koncepcja Pierre'a Legendre'a, „Studia Prawnicze KUL” 2017, nr 2 (70). 
kiej podmiotowości jako wartości politycznej, uzasadnia rezygnację $z$ idei praw człowieka o ustalonej treści. Na gruncie nowego materializmu za „podmioty praw” uznane zostaja przedmioty materialne, a idea prawa podmiotowego staje się, co najwyżej, jednym $z$ haseł politycznych, ewentualnie jedna $z$ konstrukcji prawnych, możliwą do zastapienia przez inne doktrynalne fikcje.

Nowy materializm stanowi więc w pełni konsekwentny posthumanizm, kompatybilny ze zjawiskami społecznymi oraz nurtami ideowymi konstytutywnymi dla postponowoczeności. Jawi się, przynajmniej potencjalnie, nie tylko jako ideologiczny program dalszych zmian polityczno-kulturowych, lecz również jako ideologia ponadnarodowej struktury politycznej, odchodzacej od idei państwa opiekuńczego, promującej polityczna i kulturową partykularyzację rządzonych ${ }^{88}$.

88 Być może wyrazem kształtowania się takiej konstelacji ideologicznej jest walka rządu francuskiego $z$ ruchem „żółtych kamizelek”, rozpoczęta pod hasłem spacyfikowania awanturników nie chcących rezygnować ze swych praw ekonomicznych w imię ochrony planety. 